\title{
Profil hasil pemeriksaan CT-Scan pada pasien karsinoma nasofaring di Bagian/SMF Radiologi FK Unsrat RSUP Prof. Dr. R. D. Kandou Manado periode April 2015 - Agustus 2016
}

\author{
${ }^{1}$ Matthew N. Ruslim \\ ${ }^{2}$ Ramli Hadji Ali \\ ${ }^{2}$ Elvie Loho
}

\author{
${ }^{1}$ Kandidat Skripsi Fakultas Kedokteran Universitas Sam Ratulangi Manado \\ ${ }^{2}$ Bagian/SMF Radiologi Fakultas Kedokteran Universitas Sam Ratulangi Manado \\ Email: matthewnathanaelruslim@gmail.com
}

\begin{abstract}
Nasopharyngeal carcinoma is the most common malignancy of the head and neck. In Indonesia, the prevalence is 6/100.000 and Manado has become one of the regions with the highest incidence of nasopharyngeal carcinoma. CT Scan imaging is a standard radiologic modality in diagnosing and evaluating nasopharyngeal carcinoma. This study was aimed to obtain the profile of CT Scan imaging in nasopharyngeal carcinoma patients. This was a retrospective descriptive study conducted in October 2016. Data were obtained from head and neck CT Scan request form and eventually there were 46 patients $(63 \%)$ with the radiologic diagnosis of tumor mass in the nasopharynx. The majority of patients were males (30 patients; 65,2\%); age group 50-59 years old (17 patients; $37 \%$ ); and T4 as the size of the primary tumor (18 cases; $39.1 \%)$. There were five anatomical structures most frequently infiltrated, as follows: nasal cavity (39.1\%), ethmoidal sinuses (30.4\%), maxillary sinuses (23.9\%), sphenoidal sinuses (23.,9\%), and intracranial areas (19.6\%).
\end{abstract}

Keywords: nasopharyngeal carcinoma, computerized tomography scan.

\begin{abstract}
Abstrak: Karsinoma nasofaring merupakan keganasan kepala dan leher yang paling sering terjadi. Indonesia memiliki prevalensi sekitar 6/100.000 dan Manado menjadi salah satu daerah dengan insidensi karsinoma nasofaring yang tinggi. Pemeriksaan radiologi CT Scan, merupakan modalitas radiologis standar dalam mendiagnosis dan mengevaluasi karsinoma nasofaring. Penelitian ini bertujuan untuk mendapatkan profil pemeriksaan CT Scan pada pasien karsinoma nasofaring. Jenis penelitian ialah deskriptif retrospektif yang dilakukan pada bulan November 2016. Data diperoleh melalui lembaran permintaan pemeriksaan CT Scan kepala-leher dan didapatkan sebanyak 46 pasien (63\%) dengan diagnosis radiologis massa tumor di nasofaring. Mayoritas pasien ialah ialah laki-laki berjumlah 30 pasien $(65,2 \%)$, kelompok usia 50-59 tahun berjumlah 17 pasien (37\%), dan ukuran tumor primer T4, pada 18 pasien $(39,1 \%)$. Didapatkan lima struktur anatomi yang paling sering diinfiltrasi, yaitu kavum nasi $(39,1 \%)$, sinus etmoidalis $(30,4 \%)$, sinus maksilaris $(23,9 \%)$, sinus sfenoidalis $(23,9 \%)$, dan area intrakranial $(19,6 \%)$.
\end{abstract}

Kata kunci: karsinoma nasofaring, computerized tomography scan

Kanker adalah sekelompok penyakit yang dikarakteristikkan sebagai tidak terkontrolnya pertumbuhan dan penyebaran dari sel yang abnormal. Bila penyebarannya tidak dikendalikan maka dapat menyebabkan kematian. Kanker disebabkan oleh faktor eksternal (rokok, organisme infeksius, dan makanan yang tidak sehat) dan internal (mutasi genetik yang diwariskan, hormon, dan kondisi imun). Faktor-faktor risiko ini dapat menyebabkan kanker secara bersamaan atau bertahap. Kanker dapat 
terdeteksi setelah 10 tahun lebih sejak terpaparnya faktor eksternal. ${ }^{1}$ Berdasarkan statistik GLOBOCAN 2012, penyakit kanker telah mencapai sekitar 14,1 juta kasus baru dan terdapat 8,2 juta kematian, ${ }^{2}$ sebab itu kanker mendapatkan peringkat kedua penyebab kematian penduduk dunia. ${ }^{1}$

Karsinoma nasofaring merupakan keganasan kepala dan leher yang paling sering terjadi dengan etiologi yang multifaktorial dan dibedakan menurut distribusi geografisnya. ${ }^{3}$ Etiologi yang paling kuat menyebabkan karsinoma nasofaring ialah Epstein Barr virus, yang terbukti dari studi serologik dan terdeteksinya genom Epstein Barr virus pada sampel tumor. Makanan dan genetik merupakan faktor risiko yang masih menjadi kemungkinan penyebab terjadinya karsinoma nasofaring. ${ }^{4}$ Rokok dan alkohol menjadi faktor risiko yang kecil kontribusinya. ${ }^{5}$

Secara global, karsinoma nasofaring sangat jarang terjadi karena hanya 80.000 kasus baru yang dilaporkan, dengan demikian karsinoma nasofaring menjadi peringkat ke-23 diantara kasus kanker lainnya di dunia. Di Amerika Utara dan Eropa, insidensinya kurang dari 1 kasus per 100.000 penduduk, tetapi di daerah yang endemik seperti Cina Selatan dan Asia Tenggara, insidensinya bisa mencapai 20 sampai 40 kasus per 100.000 penduduk pria dan 8 sampai 15 kasus per 100.000 penduduk wanita. ${ }^{6}$ Negara-negara di Asia Tenggara juga mempunyai insidensi yang cukup tinggi, seperti Singapura (15/100.000), Malaysia (9,7/100.000), Vietnam (7,5/100.000), dan Filipina $(6,4 / 100.000) .^{7} \quad$ Menurut salah satu penelitian, Indonesia memiliki prevalensi sekitar 6/100.000, yang berhubungan dengan estimasi yang dilaporkan dari GLOBOCAN-International Agency for Research on Cancer (GLOBOCANIARC). ${ }^{7}$

Sarana penunjang radiologi yang menjadi standar dalam mendiagnosis tumor yaitu pemeriksaan Computerized Tomography (CT) Scan. Pemeriksaan CT Scan ini dapat membantu dalam menentukan lokasi, karakteristik dan stadium pada pasien-pasien dengan tumor. Pada kasus karsinoma nasofaring, CT Scan dapat memberikan informasi tentang penyebaran kelenjar getah bening, infiltrasi jaringan sekitarnya, dan destruksi tulangtulang terutama pada basis krani.

Penulis termotivasi untuk melakukan penelitian tentang karsinoma nasofaring yang didiagnosis melalui pemeriksaan radiologi CT Scan, karena penelitian ini belum pernah dilakukan sebelumnya. Penelitian ini didukung dengan adanya pasien karsinoma nasofaring serta permintaan CT Scan di Bagian Radiologi FK Unsrat/SMF RSUP Prof. Dr. R. D. Kandou Manado selama periode April 2015-Agustus 2016.

\section{METODE PENELITIAN}

Jenis penelitian ini ialah deskriptif retrospektif dengan memanfaatkan data sekunder berupa catatan medik yang ada di lembaran permintaan pemeriksaan CT Scan di Bagian Radiologi FK Unsrat/SMF RSUP Prof. Dr. R. D. Kandou Manado. Penelitian dilaksanakan pada bulan November 2016.

Populasi penelitian ini ialah seluruh lembaran permintaan pemeriksaan CT Scan kepala-leher di Bagian Radiologi RSUP Prof. Dr. R. D. Kandou Manado periode April 2015-Agustus 2016. Sampel penelitian ini ialah seluruh lembaran permintaan pemeriksaan CT Scan pada pasien dengan diagnosis radiologis massa tumor di nasofaring di Bagian Radiologi FK Unsrat/SMF RSUP Prof. Dr. R. D. Kandou Manado periode April 2015 Agustus 2016. Kriteria inklusi yaitu lembaran permintaan pemeriksaan CT Scan kepala-leher dari pasien dengan klinis mengarah karsinoma nasofaring yang mempunyai data berupa usia dan jenis kelamin serta mempunyai hasil ekspertisi sedangkan kriteria eksklusi yaitu lembaran permintaan CT Scan kepala-leher dari pasien yang sudah melakukan terapi sebelumnya dan pasien yang mengalami rekurensi. Penelitian ini menggunakan 2 variabel yakni hasil ekspertise pemeriksaan CT Scan kepala-leher dan karsinom 
nasofaring yang didistribusi menurut jenis kelamin, kelompok usia dan tumor primernya.

Data yang diperoleh diolah berdasarkan variabel penelitian dengan menggunakan SPSS dan disajikan dalam bentuk teks dan tabel.

\section{HASIL PENELITIAN}

Pada bulan Oktober 2016 telah dilakukan penelitian dengan mengambil data sekunder berupa lembaran permintaan pemeriksaan CT Scan kepala-leher pada penderita dengan klinis yang mengarah pada karsinoma nasofaring. Penelitian ini dilakukan secara retrospektif di Bagian/SMF Radiologi FK Unsrat RSUP Prof. Dr. R. D. Kandou, Manado periode April 2015 - Agustus 2016. Berdasarkan hasil penelitian, ditemukan 73 lembar permintaan pemeriksaan CT Scan kepalaleher pasien dengan klinis yang mengarah pada karsinoma nasofaring. Hasil ekspertise dari 73 lembar permintaan CT Scan pasien tersebut, terdapat 46 pasien yang ditemukan massa di nasofaring.

Pasien dengan diagnosis radiologis massa tumor di nasofaring sebanyak 46 pasien $(63 \%)$ dan pasien dengan diagnosis radiologis lainnya sebanyak 16 pasien $(21,9 \%)$. Pasien yang tidak ditemukan kelainan pada hasil pemeriksaannya sebanyak 6 pasien $(8,2 \%)$. Terdapat pasien yang melakukan pemeriksaan CT Scan untuk kontrol pasca kemoterapi sebanyak 3 pasien $(4,1 \%)$. Ditemukan juga pasien yang mengalami rekurensi sebanyak 1 pasien $(1,4 \%)$ dan yang tidak dilampirkan hasil ekspertise berjumlah 1 pasien $(1,4 \%)$.

Tabel 1. Distribusi pasien karsinoma nasofaring berdasarkan diagnosis radiologis

\begin{tabular}{ccc}
\hline Diagnosis radiologis & $\mathbf{n}$ & $\mathbf{\%}$ \\
\hline Tumor primer di nasofaring & 46 & 63 \\
Kelainan lainnya & 16 & 21,9 \\
Tidak ada kelainan & 6 & 8,2 \\
Pasien post kemoterapi & 3 & 4,1 \\
Pasien rekurensi & 1 & 1,4 \\
Tidak ada hasil ekspertise & 1 & 1,4 \\
Total & 73 & 100 \\
\hline
\end{tabular}

Berdasarkan Tabel 2 didapatkan bahwa karsinoma nasofaring paling banyak ditemukan pada laki-laki dengan jumlah 30 pasien $(65,2 \%)$ dan perempuan berjumlah 16 pasien $(34,8 \%)$.

Tabel 2. Distribusi pasien karsinoma nasofaring berdasarkan jenis kelamin

\begin{tabular}{ccc}
\hline Jenis kelamin & n & \% \\
\hline Laki-Laki & 30 & 65,2 \\
Perempuan & 16 & 34.8 \\
Total & 46 & 100 \\
\hline
\end{tabular}

Pada data yang didapat dari 46 pasien dengan diagnosis radiologis massa tumor di nasofaring ditemukan pasien termuda berusia 32 tahun dan tertua berusia 84 tahun. Berdasarkan Tabel 3, kasus karsinoma nasofaring terbanyak didapatkan pada kelompok usia 50-59 tahun yaitu 17 pasien (37\%) diikuti kelompok usia 60-69 tahun sebanyak 14 pasien $(30,40 \%)$. Kelompok usia 70-79 tahun dan kelompok usia 80-90 tahun paling sedikit ditemukan pasien karsinoma nasofaring, yaitu masingmasing didapatkan 1 pasien $(2,2 \%)$.

Hasil ekspertise dari 46 pasien dengan diagnosis radiologis massa tumor di nasofaring diklasifikasikan berdasarkan tumor primer (T) menurut The International Union Against Cancer (UICC) \& American Joint Committee on Cancer (AJCC), edisi ke-7 (2010). ${ }^{13}$

Tabel 3. Distribusi pasien karsinoma nasofaring berdasarkan umur

\begin{tabular}{ccc}
\hline Kelompok usia & $\mathbf{n}$ & $\mathbf{\%}$ \\
\hline 30-39 tahun & 7 & 15,2 \\
40-49 tahun & 6 & 13 \\
50-59 tahun & 17 & 37 \\
60-69 tahun & 14 & 30,4 \\
70-79 tahun & 1 & 2,2 \\
80-90 tahun & 1 & 2,2 \\
Total & 46 & 100 \\
\hline
\end{tabular}

Berdasarkan Tabel 4, ukuran tumor primer pasien yang tersering terdiagnosis yaitu T4 dengan jumlah 18 pasien $(39,1 \%)$, kemudian yang terdiagnosis dengan ukuran 
T1 berjumlah 12 pasien $(26,1 \%)$ dan yang terdiagnosis dengan ukuran $\mathrm{T} 2$ dan $\mathrm{T} 3$ masing-masing memiliki jumlah yang sama, yaitu 8 pasien $(17,4 \%)$.

Tabel 4. Distribusi pasien karsinoma nasofaring berdasarkan tumor primer $(\mathrm{T})$

\begin{tabular}{ccc}
\hline Ukuran tumor & $\mathbf{n}$ & $\mathbf{\%}$ \\
\hline T1 & 12 & 26,1 \\
T2 & 8 & 17,4 \\
T3 & 8 & 17,4 \\
T4 & 18 & 39,1 \\
Total & 46 & 100 \\
\hline
\end{tabular}

Berdasarkan Tabel 5 ditemukan lima struktur anatomi yang paling sering diinfiltrasi oleh massa di nasofaring, yaitu kavum nasi $(39,1 \%)$, sinus etmoidalis $(30,4 \%)$, sinus maksilaris $(23,9 \%)$, sinus sfenoidalis $(23,9 \%)$, dan area intrakranial $(19,6 \%)$. Pada penelitian ini telah ditemukan struktur anatomi seperti clivus, fossa cranii posterior, foramen ovale, foramen lacerum, lidah, tonsil, dan telinga jarang mengalami infiltrasi yang masingmasing terdapat 1 pasien $(2,2 \%)$.

Tabel 5. Struktur anatomi sekitar nasofaring yang diinfiltrasi oleh massa tumor

\begin{tabular}{lcc}
\hline Struktur anatomi & $\mathrm{n}$ & $\%$ \\
\hline Kavum nasi & 18 & 39,1 \\
Sinus maksilaris & 11 & 23,9 \\
Sinus etmoidalis & 14 & 30,4 \\
Sinus sfenoidalis & 11 & 23,9 \\
Sinus frontalis & 4 & 8,7 \\
Kelenjar parotis & 7 & 15,2 \\
Intrakranial & 9 & 19,6 \\
Fossa pterygoidea & 3 & 6,5 \\
Clivus & 1 & 2,2 \\
Fossa Cranii Posterior & 1 & 2,2 \\
Otot mastikator & 3 & 6,5 \\
Palatum durum & 2 & 4,3 \\
Sella Turcica & 2 & 4,3 \\
Foramen Ovale & 1 & 2,2 \\
Lidah & 1 & 2,2 \\
Tonsil & 1 & 2,2 \\
Retrobulbar & 2 & 4,3 \\
Telinga & 1 & 2,2 \\
Foramen lacerum & 1 & 2,2 \\
\hline
\end{tabular}

\section{BAHASAN}

Berdasarkan hasil ekspertise dari 73 lembar permintaan CT Scan pasien tersebut, terdapat 46 pasien dengan diagnosis radiologis massa tumor di nasofaring. Hal ini menunjukkan bahwa karsinoma nasofaring masih merupakan kasus yang cukup sering ditemukan di dunia medis. CT Scan kepala-leher menjadi salah satu modalitas yang digunakan dalam mendiagnosis karsinoma nasofaring. ${ }^{1,8}$ Pada hasil ekspertise dari 46 pasien, didapatkan gambaran massa yang berlokasi di nasofaring yang kebanyakan tampak hipodens, dan ketika diberikan kontras tampak menyangat. Menurut Maharjan et al. ${ }^{9}$ karsinoma nasofaring merupakan massa jaringan lunak yang nilai atenuasi CT Scan menunjukan 35-45 Hounsfield Unit (HU). Pemeriksaan dengan CT Scan kontras, massa karsinoma nasofaring menyangat kontras dengan cukup baik.

Pasien karsinoma nasofaring terbanyak didapatkan pada laki-laki sebanyak 68,2\% dibandingkan pada perempuan $34,2 \%$. Hasil penelitian ini sesuai dengan penelitian yang dilakukan oleh Adham et al. ${ }^{7}$ di RSUPN Cipto Mangunkusumo tahun 2012 bahwa dari 1121 data pasien terdiagnosis karsinoma Nasofaring dari tahun 1995-2005, dijumpai lebih banyak pada jenis kelamin laki-laki yaitu 789 pasien $(70,4 \%)$ dan pada perempuan sebanyak 332 pasien $(29,6 \%)$. Menurut Jia et al. ${ }^{10}$ insidens karsinoma nasofaring yang ditemukan pada laki-laki dua sampai tiga kali lipat lebih tinggi dibandingkan perempuan. Perbedaan jumlah antara lakilaki dan perempuan menunjukan efek dari kebiasan dan gaya hidup, contohnya seperti merokok dan minum alkohol. Perbedaan ini juga bisa disebabkan perbedaan biologis antara laki-laki dan perempuan. ${ }^{10}$

Kasus karsinoma nasofaring paling sering didapatkan pada kelompok usia 5059 tahun dengan jumlah 17 pasien (37\%), diikuti dengan kelompok usia 60-69 tahun dengan jumlah 14 pasien $(30,4 \%)$. Pernyataan Jia et al. ${ }^{10}$ menyatakan bahwa insidens karsinoma nasofaring meningkat pada orang dewasa dengan puncaknya pada 
kelompok usia 50-59 tahun yang sesuai dengan hasil penelitian ini. Penelitian yang dilakukan oleh Ardham et al. ${ }^{7}$ menunjukkan hasil yang berbeda. Pada penelitian yang dilakukan di RSUPN Cipto Mangunkusumo juga menemukan bahwa kasus karsinoma nasofaring paling sering terjadi di kelompok usia 41-50 tahun. Tingginya insidens karsinoma nasofaring juvenil menunjukkan kerentanan genetik dan paparan pada zat-zat karsinogen di lingkungan.

Hasil ekspertise pemeriksaan CT Scan kepala-leher dari 46 pasien telah diklasifikasikan berdasarkan tumor primer (T) menurut The International Union Against Cancer (UICC) \& American Joint Committee on Cancer (AJCC) edisi ke-7. ${ }^{11}$ Ukuran tumor primer yang paling sering ditemukan ialah T4 dengan jumlah 18 pasien $(39,1 \%)$, yang berarti banyak pasien datang sudah dengan stadium IV. Hasil ini sesuai dengan penelitian yang dilakukan di Malaysia pada tahun 2007 dengan menggunakan klasifikasi AJCC edisi ke-6, yaitu banyak pasien datang sudah dengan stadium IV berjumlah 78 pasien $(47 \%){ }^{12}$

Pada penelitian ini, ditemukan lima struktur anatomi yang paling sering diinfiltrasi oleh massa di nasofaring, yaitu kavum nasi $(39,1 \%)$, sinus etmoidalis $(30,4 \%)$, sinus maksilaris $(23,9 \%)$, sinus sfenoidalis $(23,9 \%)$, dan area intrakranial $(19,6 \%)$. Penelitian Sham et al. ${ }^{13}$ menemukan hasil yang berbeda yaitu struktur yang paling sering terlibat ialah sinus sfenoidalis $(26,7 \%)$, fosa nasal $(21,8 \%)$, dan sinus etmoidalis $(18,3 \%)$.

Infiltrasi pada struktur-struktur anatomi disekitar nasofaring dapat menyebabkan kelainan neurologis dengan melibatkan saraf-saraf yang melewati struktur-struktur anatomi tersebut. Infiltrasi pada kavum nasi dapat melibatkan cabang nervus kranial V2 (divisi maksilaris) yang berada di fosa pterigopalatinus melalui foramen sfenopalatinus. Infiltrasi pada sinus etmoidalis dapat melibatkan cabang saraf nasosiliar dan saraf optik, dan nervus kranial yang terlibat ialah nervus V1 (divisi oftalmikus), I, II,III, IV, dan abdusens.
Infiltrasi sinus maksilaris dapat melibatkan cabang saraf aveolar superior yang merupakan salah satu cabang nervus kranial V2. Infiltrasi pada palatum dapat melibatkan cabang saraf palatinus mayor dan minor yang merupakan cabang nervus kranial V2 yang berada di fosa pterigopalatinus. Infiltrasi massa ke lidah dapat menyebabkan gangguan nervus kranial XII (nervus hypoglossus). Infiltrasi pada kelenjar parotis dapat melibatkan cabang nervus kranial VII dan saraf auriculotemporal cabang dari nervus kranial V3 (divisi mandibular). ${ }^{14}$ Infiltrasi ke intrakranial yang sering ditemukan pada pasien dengan ukuran tumor primer $\mathrm{T} 4$ akan memberikan gejala neurologik. Pasien yang mengalami infiltrasi secara langsung pada sinus cavernosus dapat menyebabkan multiple cranial palsies. ${ }^{15}$

Pada penelitian ini, ditemukan sebuah kasus yang hasil ekspertisenya menunjukkan massa tumor di nasofaring dengan infiltrasi ke intrakranial tanpa ada destruksi tulang-tulang dan sinus paranasalis. Temuan ini sesuai dengan hasil penelitian yang dilakukan Miura et al. ${ }^{16}$ bahwa penyebaran ke intrakranial dapat melalui foramen tanpa destruksi tulang-tulang disekitarnya.

\section{SIMPULAN}

Dari hasil penelitian yang telah dilakukan di Bagian/SMF Radiologi RSUP/SMF Radiologi RSUP Prof. R. D. Kandou Manado selama periode April 2015-Agustus 2016, dapat disimpulkan bahwa dari 46 pasien dengan diagnosis radiologis massa tumor di nasofaring, didapatkan tersering ialah jenis kelamin laki-laki, usia 50-59 tahun. Ukuran tumor primer yang paling banyak terdiagnosis yaitu T4 dan lima struktur anatomi di sekitar nasofaring yang paling sering mengalami infiltrasi ialah kavum nasi, sinus etmoidalis, sinus maksilaris, sinus sfenoidalis, dan intrakranial.

\section{SARAN}

Disarankan agar memperhatikan kelengkapan data klinis pasien untuk 
pertimbangan diagnosis radiologis. Pelaporan hasil ekspertise harus sesuai prosedur. Pencegahan terhadap faktor resiko untuk menurunkan angka kejadian penyakit karsinoma nasofaring dengan memperbaiki kebiasaan gaya hidup seperti merokok, minuman beralkohol dan juga makan makanan yang bergizi.

Penelitian yang lebih lanjut tentang karsinoma nasofaring sangat disarankan karena penelitian ini masih kurang dilakukan di Indonesia.

\section{DAFTAR PUSTAKA}

1. American Cancer Society. Global Cancer Facts \& Figures (3rd ed). Atlanta: American Cancer Society, 2015. [cited 2016 August 25 ] Available from: www.cancer.org/acs/groups/content/@r esearch/documents/.../acspc044738.pdf

2. Torre LA, Bray F, Siegel RL, Ferlay J, Tieulent JL, Jemal A. Global cancer statistics 2012. Cancer J Clin. 2015;65:87-108.

3. Argiris A, Eng C. Epidemiology, staging, and screening of head and neck cancer. In: Brockstein B, Masters G. Head and Neck Cancer. Dordrecht: Kluwer Academics Publishers, 2004; p. 15-31.

4. Waes CV, Haglund KE, Conley BA. Head and neck cancer. In: Abraham J, Gulley JL, Allegra CJ. Bethesda Handbook of Clinical Oncology (4th ed). Lippincott Williams \& Wilkins; 2014; p. 19-20.

5. Chang ET, Adami HO. The enigmatic epidemiology of nasopharyngeal carcinoma. Cancer Epidemiol Biomarkers Prev. 2006;15(10):176577.

6. Union for International Cancer Control, Nasopharyngeal carcinoma. In: Review of Cancer Medicines. WHO List of Essential Medicines. 2014. [cited 2016 August 25] Available from: www.who.int/selection_medicines/com mittees/.../NasopharyngealCarcinoma.p df?ua=1

7. Adham M, Kurniawan AN, Muhtadi AI, Roezin A, Hermani B, Gondhowiardjo $\mathrm{S}$, et al. Nasopharyngeal carcinoma in Indonesia: epidemiology,incidence, signs, and symptoms at presentation. Chin J Cancer. 2012;1:185-96.

8. Depkes. Protokol Kanker Nasofaring. PP. POI.

9. Maharjan R, Xiang ZW, Shi F, Wu KT, Li CX. Nasopharyngeal carcinoma: Imaging diagnosis and recent progress. J Nasopharyng Carcinoma. 2014;1(1):e1.

10. Jia WH, Qin HD. Non-viral environmental risk factors for nasopharyngeal carcinoma: A systematic review. Seminars in Cancer Biology. 2012;22:117-26.

11. Li J, Zou X, Wu YL, Guo JC, Yun J-P, Xu $\mathbf{M}$, et al. A comparison between the sixth and seventh editions of the UICC/AJCC staging system for nasopharyngeal carcinoma in a Chinese cohort. PLoS ONE. 2014;9(12):5.

12. Pua KC, Khoo ASB, Yap YY, Subramaniam SK, Ong CA, Khrisnan GG, et al. Nasopharyngeal carcinoma database. Med J Malaysia. 2008;63 Supplement C:59-62.

13. Sham JST, Cheung YK, Choy D, Chan FL, Leong L. Nasopharyngeal carcinoma: CT evaluation of patterns of tumor spread. AJNR. 1991;12:265-70.

14. Moonis G, Cunnane MB, Emerick K, Curtin H. Patterns of perineural tumor spread in head and neck cancer. Magn Reson Imaging Clin N Am. 2012;20:435-446.

15. Razek AAKA, King A. MRI and CT of nasopharyngeal carcinoma. AJR 2012;198:11-18.

16. Miura T, Hirabuki N, Nishiyama $K$, Hashimoto T, Kawai R, Yoshida J, et al. Computed Tomographic findings of nasopharyngeal carcinoma with skull base and intracranial involvement. Cancer. 1990;65:29-37. 